\title{
Article
}

\section{Women as co-offenders: Pathways into crime and offending motivations}

Barlow, Charlotte and Weare, Siobhan

Available at http://clok.uclan.ac.uk/39815/

Barlow, Charlotte ORCID: 0000-0002-1362-7131 and Weare, Siobhan (2019) Women as co-offenders: Pathways into crime and offending motivations. The Howard Journal Of Criminal Justice, 58 (1). pp. 86-103. ISSN 0265-5527

It is advisable to refer to the publisher's version if you intend to cite from the work. http://dx.doi.org/10.1111/hojo.12292

For more information about UCLan's research in this area go to

http://www.uclan.ac.uk/researchgroups/ and search for < name of research Group>.

For information about Research generally at UCLan please go to http://www.uclan.ac.uk/research/

All outputs in CLoK are protected by Intellectual Property Rights law, including Copyright law. Copyright, IPR and Moral Rights for the works on this site are retained by the individual authors and/or other copyright owners. Terms and conditions for use of this material are defined in the policies page.

\section{CLoK}

Central Lancashire online Knowledge www.clok.uclan.ac.uk

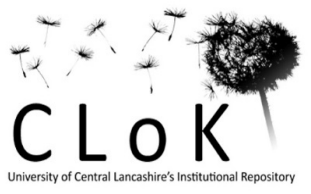




\title{
Women as co-offenders: Pathways into Crime and Offending Motivations
}

\begin{abstract}
This article reports on a qualitative study in the UK of women as co-offenders, their pathways into crime and offending motivations. What was found in the analysis of the women's narratives was that whilst co-offending relationships were a central pathway into offending, this often intersected with other circumstances in the women's lives, including drug addiction, socio-economic circumstances and 'significant life events'. These findings suggest work with this cohort of women must recognise the complexities and contexts of co-offending to understand and accurately represent women's experiences.
\end{abstract}

\section{Acknowledgements}

The authors would like to thank the reviewers and colleagues at Lancaster University Law School Peer Review College for their invaluable feedback on earlier versions of the paper. We would also like to extend our sincerest thanks to the women who shared their stories with us.

\section{Introduction}

Despite a growing body of work exploring women's involvement in crime, less scholarly consideration has been given to women's pathways into crime when they are involved in cooffending. Co-offending is defined here as the act of committing crime alongside one or more accomplices (Carrington, 2002). Although co-offending has been recognised as an inherent part of delinquency (Conway and McCord, 2002), the existing criminological literature in this 
area has tended to focus on juvenile samples (Warr, 1996; McGloin et al, 2008), male offenders (Reiss \& Farrington, 1991) or particular crimes, e.g. violence (Pettersson, 2005). Furthermore, most of the research which has considered female co-offending has been conducted in the USA and concerns organised drug-dealing and related violence (see, eg. Welle \& Falkin, 2000). Consequently, women's involvement in co-offending as a pathway into crime is one that has received limited consideration in the existing literature. Indeed, the focus has been on women offenders more broadly, or those who commit certain offences (see, e.g. Seal, 2010, removed for review 2013; 2017) and in the USA in particular, the emphasis has been to analyse the distinct and often gendered pathways into crime that women take (Daly, 1994). As a result, co-offending is often written about as an 'aside' within the female offending literature, with limited attention given to the specific ways in which cooffending partnerships can both motivate women's offending and act as a pathway into crime. The limited literature in the area typically focusses on the extent to which such women are forced or coerced into crime by their male partner/ co-offender (Jones, 2008; removed for review, 2016) or focuses on the impact of the relationship itself (Welle and Falkin, 2000) on women's offending.

Research and policy has increasingly considered the ways in which substance misuse, socioeconomic circumstance and other structural constraints influence women offenders pathways into crime (Batchelor, 2009; Corston, 2007). However, this research does not consider the influence of co-offending specifically. Nowhere within current research is consideration given to the potential for multiple factors to overlap in the lives of co-offending women, a combination of which motivates them to offend. 
As such, this article makes a novel contribution to knowledge by critically considering not only the impact of co-offending relationships on women's criminality, but also additional factors which intersect with these relationships within their lives. We share the results of a research study involving in-depth qualitative interviews with women who have co-offended in the UK. Analysis of the women's experiences highlights the complexities of both their pathways into crime and their continued offending motivations. Whilst co-offending relationships were central to the women's pathways into criminality, other factors including drug addiction, socio-economic circumstances, and what we term 'significant life events' were all relevant to the women's offending motivations. On several occasions, these factors directly intersected with women's co-offending relationships, highlighting both the complexities of their lives, and their choices, something which many of the women themselves emphasised within their narratives.

\section{Literature Review}

From the 1970 's onwards, particularly in the USA, a body of work collectively termed 'feminist pathways' research sought to explain how and why women become involved in the criminal justice system (Daly, 1994; Richie, 1996; Belknap, 2007; Chesney-Lind \& Shelden, 2004). This research developed as a result of the pathways literature of the time devoting insufficient attention to female offenders, and concerns raised by feminist scholars about whether theories developed 'by men, about men' could account for women's experiences (Daly \& Chesney-Lind, 1996; Walklate, 2001). The feminist pathways research produced compelling narratives of women offenders' experiences, and identified key issues and risks that often characterise women's pathways into crime and consequential continued offending 
motivations. These include the impacts of childhood victimisation, extreme marginalisation through education and employment issues, mental health issues and substance abuse, and the impact of relationships, particularly those with a violent man (Covington 1988; Gilligan 1982; Daly, 1994; Richie 1996). Whilst there is some gender overlap in these pathways and offending motivations when compared to those taken by men, there are some qualitative differences in those taken by women, meaning that not all are applicable to, or a 'good fit' for, men's experiences (Simpson et al., 2008: 86).

The relatively small body of research exploring women's co-offending has suggested that women often engage in more serious offending with a male partner than when they do so alone (Mullins \& Wright, 2003; Koons-Witt and Schram, 2003), and that they are more likely to engage in gender atypical offences when they co-offend with a man, such as robbery and murder (Becker and McCorkel, 2011). Scholars have also focused specifically on the experiences of women who are in an intimate relationship with their male co-offender. For example, Welle and Falkin (2000) have suggested that these women often experience 'relationship policing', which involves many aspects of their relationship and life, including participation in criminal activity, being controlled by their romantic co-offender. The intersecting inequalities of race and gender have also been considered in relation to cooffending women's experiences. Richie (1996: 133) has argued that an intersection of gender and racial inequality can lead women to be 'compelled' into a variety of criminal and deviant behaviours, with the notion of 'gender entrapment' helping "to show how some women are forced or coerced into crime by their culturally expected gender roles, the violence in their intimate relationships and their social position in the broader society." Moreover, Jones (2008) has suggested that women who co-offend with intimate male partners can have their 
involvement categorised in three key ways: acting as a result of coercion, offending 'out of love', and adopting an 'equal' role in the offending.

The focus within existing research on women who co-offend with romantic male partners means the issue of agency is one that is "a central feature of the research literature on malefemale collaborations. Were [the women] fully independent agents exercising a rational choice to act in a particular way, or were they effectively coerced into behaving in the way they did?" (Jones 2008: 149). Indeed, the possibility of coercion within such co-offending partnerships introduces important discussions regarding agency and choice. The current approach by scholars is typically dichotomous, with some resisting the centralisation of agency and instead focusing on women's coercion and victimisation (see e.g. Jones 2008), and others focusing on acknowledging women's agency and thus challenging perceptions that women are less capable of rationality, reflection, and decision-making than men (see e.g. Morrisey, 2003). The existing dichotomy of approaches taken to the issue of women's agency has made it difficult to develop nuanced and representative understandings of how agency is exercised within co-offending relationships. Consequently, this is something which this paper aims to address.

As summarised above, the small body of existing research on women's co-offending has almost exclusively focused on the impact that intimate relationships with men have on women's involvement in crime, often focussing on them being coerced or forced into crime. Whilst developing insights into intimate co-offending partnerships, this approach has prescriptively categorised women's criminality in relation to the types of co-offending relationships they are involved in (Jones 2008), and their pathways into crime (Jones, 2011; Welle and Falkin, 2000). The women offenders themselves have also been categorised (Daly, 
1994). Moreover, the focus on romantic co-offending relationships within existing research has meant that a distinct lack of consideration has been given to intersections between cooffending relationships and other factors which impact women's pathways into crime and their offending motivations, as well as their perceived choices in relation to criminal behaviour. Other co-offending relationships, for example with female friends, have also gone largely undiscussed (except in the context of female gang violence, see, e.g. Lauderdale \& Burman, 2009).

This article aims to begin to fill these gaps in the literature, making a unique contribution to knowledge by exploring multiple and over-lapping factors that influence women cooffenders' pathways into crime, such as their relationships, both romantic and otherwise, with co-offenders, and their offending motivations, such as drugs and poverty. Rather than essentialising the ways in which co-offending relationships influence women's pathways into crime, we recognise the complexities of women's experiences through a centralisation of their first-hand narratives. In this way, we encapsulate the complicated lives of women cooffenders and how this impacts their pathways into crime and offending motivations. In presenting our findings we move away from focussing solely on women's roles in co-offending and the categorisation approach previously taken, instead looking at some of the broader overarching themes that have emerged in the data collected.

\section{Methodological Approach}

The aims of this research were to investigate co-offending women's pathways into, and motivations for engaging in, criminal behaviour. Semi-structured interviews were conducted 
between February and May 2016 with eight women who accessed a women's advice and support centre in Staffordshire, United Kingdom.

Semi-structured, in-depth interviews were chosen as the method of data collection as they allowed for women's narratives and subjective lived experiences to be most clearly communicated. This approach also reflected the feminist methodological and epistemological approach underpinning the project; recognising the experiences of women from their own point of view (Harding, 1981; Smith, 1987). Moreover, conducting semi-structured interviews allowed us "to follow up interesting and important issues that [came] up during the interview" (Smith 2004: 50), thus allowing for the most comprehensive and detailed accounts of women's experiences to be developed. Whilst the interviews varied in length, all were prolonged and involved detailed personal discussions with participants. The study received ethical approval from both researchers' respective institutions (NAMES OMMITTED FOR REVIEWING PURPOSES). Before beginning the interviews, both researchers spent time at the women's centre to explain the research to potential participants, as well as to staff. Posters were also put up to share details of the project.

The women who participated in the study arguably do not constitute a representative sample; all participants were of the same ethnicity (white) and living in the Staffordshire area in the UK. They also formed part of a purposive, rather than random sample, with the focus of the study being specifically on women who had co-offended. In terms of their offending behaviour, participants had committed a range of relatively 'low-level' offences, including theft, buying and selling drugs, drug use, and benefit fraud. Access to participants was facilitated by the women's centre, and all interviews took place on these premises as a 'safe space' for both participants and researchers. Drawing all participants from the women's 
centre, and interviewing them there, could have influenced the information provided, not least because all of the women involved were in a 'rehabilitative journey' of sorts in relation to their offending. However, this limitation of the study was countered by the fact that interviewing women who have offended is often challenging due to their vulnerabilities (Worrall \& Gelsthorpe, 2009) and the sometimes-chaotic lives they can lead (Carlen, 1988). Facilitating the interviews through the women's centre was therefore the most appropriate way for the researchers to engage with, and for participants to share, important perspectives on the issues under consideration. To help minimise any potential negative impact of the women's centre, interviews were conducted without the presence of centre staff, unless requested by participants. It was also made clear that information provided in the interviews would remain confidential.

Once transcribed, the interviews were analysed using Interpretative Phenomenological Analysis (IPA). This method of analysis was chosen to reflect the feminist methodological approach underpinning the study, ensuring that the women's lived experiences, and how they made sense of them (Smith 2004: 40), were centralised throughout the project. Eight women were interviewed for the study, because "IPA challenges the traditional linear relationship between 'number of participants' and value of research ... with 10 participants at the higher end of most recommendations for sample sizes" (Reid et al. 2005: 22). Thus, whilst a limitation of this research could be the small number of participants, the use of IPA ensured the analysis was rigorous, and allowed the specific research aim of understanding the women's experiences from their own points of view to be met. It is not the intention for the findings of this paper to be generalizable in the scientific sense, but rather to ensure that the lived experiences of the women interviewed are captured and centralized in the research 
process (Smith et al, 2009). Feminist, qualitative research emphasizes the value of individual stories, whilst considering the broader context of women's narratives (Letherby, 2009). Indeed, as Smith et al (2009:21) note, IPA focuses upon participants' "attempts to make meanings out of their activities and to the things happening to them." Analyses of the interviews were conducted separately by both researchers and then compared to enhance inter-reliability to ensure cross-validation of the findings (Reid et al., 2005: 23).

\section{Research findings}

The findings below focus on the information provided by participants regarding their offending motivations and pathways into crime. Pathways into crime are defined here as the initial factors influencing women's offending and their involvement in the criminal justice system, whereas offending motivations are those factors which continue to influence women's offending behaviour. In sharing the research findings, we discuss the superordinate themes that emerged from the interviews. Reflecting the IPA approach, we have included “verbatim extracts from the participants' material to support the argument[s] being made, thus giving participants a voice in the project" (Smith et al., 2009: 180-181). Participants have been provided with pseudonyms and all other identifiable names and locations have been changed.

"I felt trapped": The influence of women's relationships with a romantic male co-offender

Seven of the women in our study co-offended with an intimate male partner (with all of them indicating at the time of interview that they had ended their relationships with these men). 
For six women, the intimate relationships they were in at the time were clearly a catalyst for their offending. For example, both Rachel and Laura stated that they "hadn't offended before" they met their romantic co-offender. Danielle also referenced that she "wouldn't have offended if she hadn't have met him (her ex-partner)" and similarly Vicky stated that "if we hadn't have met, maybe I wouldn't have gone down that road". Thus, for these women, the relationships with their male co-offenders seemed to form the basis for their pathways into crime. Broad themes emerged as to the form that this influence took.

Fear of their male partners played a specific role for some women. For example, Danielle stated that "I just did whatever he told me to do. I was scared of him". She referenced this in relation to her ex-partner pressuring her to smuggle drugs into prison whilst he was serving a prison sentence. Sarah echoed similar sentiments when discussing the reasons why she began and continued to co-offend with her intimate partner: "He knocked the life out of me. I didn't know who I was. I was just this little coward girl who did as he asked because I didn't know another way."

Whilst fear of romantic co-offending partners was not explicitly mentioned by all participants, it was clear that a range of abusive techniques were used by the men, both within the context of co-offending and beyond, i.e. within the intimate relationship itself. Coercive and controlling behaviour was reported by several participants. For example, Rachel explained how her ex-partner "threatened suicide" every time she tried to leave the relationship, evidencing his control and manipulation. She also discussed how he pressured her to commit benefit fraud, as they were struggling financially, mostly due to his gambling addiction. She suggested that even though he was the "mastermind" behind the plan, he "pressured" her to adopt the active role in the offending. Rachel said, "he convinced me it was because he loved 
me" and it was "always just pressure, pressure, pressure to do it". Similarly, Vicky noted how her ex-partner was "controlling and manipulative" throughout the whole relationship and that "he genuinely made me feel like the shit on his shoe".

Physical violence and abuse was also experienced. Sarah described how her ex-partner "beat me so bad, I've got false teeth and everything" and that he almost killed her on one occasion, "when he was punching me so hard in the face that I was pissing myself". Danielle also stated that her co-offender frequently "beat [her] up". The experiences of these women collectively supports existing feminist pathways literature, particularly the assertion that women offenders often adopt a relational pathway into crime, where an abusive relationship can influence offending behaviour (Daly, 1994). The women's narratives also highlight the ways in which abusive relationships with romantic co-offenders can influence their continued motivations to offend.

The overwhelmingly negative reflections of the women on their romantic co-offending relationships is further emphasised by the difficulty that they often had in explaining and understanding their own agency within the co-offending relationship. The women explained their choices to offend in various ways with Rachel saying she had "no choice" and Danielle noting that she "had to do it". Sarah however suggested that she had some degree of choice but that this was impacted by her romantic co-offender; "his stressful life gave me a stressful life and that affected my choices I guess". Vicky had a particularly conflicted understanding of her agency, initially suggesting "yes I did have a choice. Everyone has a choice don't they?" before stating:

This is going to sound weird, but I felt like a prisoner in my relationship with him. I've never been to prison before (laughs), but I suppose being with him is the closest thing 
I will get to prison. I felt trapped. I felt like I was trapped by him and the drugs and I couldn't see another option.

For Vicky there was also a clear overlap between fear of her partner (discussed above) and the love she felt for him, highlighting the complexity of both the intimate and co-offending relationship she was in. She explained how she "would have done anything for him" but also how she believed that he "took the piss out of how much I loved him" when she took the blame after being arrested for theft and shop-lifting they engaged in together. Although Vicky's experience supports previous research, highlighting that female co-offenders often take the blame for their romantic male co-offender/ intimate partner out of love (Jones, 2011), it also demonstrates how multiple and complex motivations in relation to a male partner can traverse for co-offending women. Indeed, the overlapping motivations of love and fear for Vicky, and exploitation of this by her male partner, highlight how dichotomising and categorising women's experiences can be problematic and not accurately represent their lived experiences. Moreover, Vicky clearly demonstrated loyalty to her romantic co-offender because of the intensity of her feelings for him, but she also recognised that these feelings were not necessarily reciprocated. This reflects some of Welle and Falkin's findings where "the mutuality of ... loyalty was dubious at best..." (2000: 58). As they go on to note, this finding "suggests the extent to which the romantic co-defendant relationship is defined through uneven power relations ...." (Welle and Falkin 2000: 58), something which we consider further below. 


\section{"You gotta have somebody there..." The influence of friendships}

As well as co-offending with a male ex-partner, three women had also co-offended with both male and female friends (Sarah, Jane and Danielle) and one had also engaged in gang activity (Sarah). For all of these women, the co-offending relationship with friends was not a pathway into crime, but rather a motivation to continue offending. Jane was the only participant who had solely co-offended with friends and not a romantic partner. She spent a substantial amount of time talking about co-offending with a male friend, who asked her if he could "sell heroin from her house", "in exchange for drugs", an offence that she was arrested and charged in relation to. Having had time to reflect on this experience (Jane was on probation at the time of interview and seeking support for substance abuse), she expressed that she felt her friend had taken advantage of her drug addiction for his own gain; "he thought if he got me a bit of gear (heroin), it would be alright". She referred to herself as a "soft touch" in relation to her offending role on eight occasions throughout the interview, suggesting that her passivity and feelings of being a 'pushover' were significant to perceptions of her offending motivations. She also suggested that additional co-offending friends, with whom she had shoplifted on previous occasions, had left her to "take the rap (blame)" when they were caught by the police because again, they knew she was a "soft touch":

J: But what it was, when it came down to it, it's me who took the rap. Do you know what I mean?

I: Oh right, so it was you that... it... so nobody else did?

J: Oh no, no, no, no. They just took advantage, you know what I mean? 
Despite recognising that her co-offenders often took advantage of her, she mostly blamed herself for this. For example, she suggested that she "let him (her male friend/ co-offender) take advantage of her" and she placed the responsibility on herself to be "stronger next time" if required. For Jane, emphasis was placed on relationships with her friends/ co-offenders as an offending motivation, but it was her drug addiction that was a key pathway into crime, which will be discussed later in the article.

As discussed in the previous section, both Sarah and Danielle's romantic male co-offenders significantly influenced their pathways into crime. However, from their narratives it was clear that relationships with their friends, particularly female "best friends", was a motivating factor to continue offending. Sarah explained how she would shop-lift, fight, and engage in other "gang-related" activity with her female friend/ co-offender. She stated that "everyone would say we were partners-in- crime" and that "she wasn't the boss, and I wasn't the boss. But we were probably the boss of everyone else." She also disclosed that people were "terrified" of them, particularly when they were together. Co-offending thus appeared to increase their notoriety and the fear others felt towards them. Danielle also talked of being "inseparable" from her female co-offender and friend. She suggested that they "influenced each other" regarding the type of crime that they participated in and that "they often (offended) together". Danielle also emphasised the importance of having a co-offender to maximise the possibility of offending 'success', with this being assessed against factors such as not getting caught by the police: "'Cause you gotta have somebody there. 'Cause when you're on your own, you've got to do everything. Look out and... Yeah".

Interestingly, both women separately used the phrase "bounced off each other" to describe the dynamics of the relationship with their friend within the context of co-offending. This, 
combined with the other ways they described their relationships with their female friends/cooffenders (noted above), highlights how they played more of an 'equal role' when cooffending in this context. This can be contrasted with the way that both women described cooffending with intimate male partners, which was overwhelmingly negative, and focused on the fear, control, and physical abuse involved (discussed in previous section). Indeed, the narratives in relation to female friends as co-offenders were much more positive, with both women emphasising that the "close-bond" and "trust" they shared were integral to them cooffending. Moreover, neither Sarah nor Danielle indicated that these relationships "involved any allegations of threats or coercion" (Jones 2008: 160). This positivity was also reflected in both women more readily acknowledging their own agency within the context of the cooffending relationship. For example, Sarah stated "we were both the same" and that they were both "instigators" and Danielle stated that "cause I... I chose that way to go. When I could have chose another way."

The narratives highlighted here demonstrate the potential impact of female friendships on women's continued motivations to offend. This is reinforced by the fact that both women had "cut ties" with their friend/ co-offender at the time of interview, with both suggesting that they wanted to "choose a different path" (Sarah) in life and desist from future offending. This emphasises the integral role that offending played in their friendship, as well as the ways in which this friendship influenced their motivations to offend. However, it is noteworthy that these friendships did not influence women's pathways into crime in the same way as cooffending with a male partner. This highlights the importance of gaining a nuanced of understanding the ways in which different types of co-offending relationships influence women's offending behaviour. Whilst there is some existing literature focusing on female co- 
offending, this has typically been focused around female gang violence (Chesney-Lind \& Sheldon, 2004; Batchelor, 2009) and female sex workers (Sanders, 2005). Little research has focused on women who co-offend in pairs. Exploring this as an offending motivation may be of particular importance if significance is attached to the fact that both Sarah and Danielle disclosed that their most serious criminal behaviour occurred when co-offending in this context. Indeed, the criminal capabilities and agency of women who co-offend together in pairs needs further exploration to develop better understanding of a previously unconsidered phenomenon.

\section{$\underline{\text { Influence of 'other' motivating factors }}$}

Whilst multiple other factors motivated participants' offending behaviours, we have focused only on those that appeared in the narratives of two or more women to allow more in-depth analysis to be undertaken. Consequently, we focus on the following; drugs, economic circumstances, and what we term 'significant life events.'

\section{Drugs}

Three women indicated that drug-addiction was both an offending motivation and a pathway into crime, reinforcing the already recognised link between drugs and offending behaviour (Wincup, 2016; Surratt et al, 2004). All three women were very clear on the impact that drugtaking had on their continued involvement in offending. Danielle explained; "I wouldn't have done any of that if it weren't for the drugs ... Every one's to do with drugs ... 'Cause when I'm not on the drugs, I don't do nothing (offend)". For Jane drug-taking was her initial pathway into crime; "I think it all ties in with drugs to be honest ....'Cause when you're on heroin, that's 
your life ... You need it". Finally, Vicky explained; "I just thought about the drugs. We just needed the drugs and did what it took to get them ...everything was based around drugs".

All three women highlighted a clear link between their drug-taking and relationships with their co-offenders. The specifics of the link varied for each of the women. The most extreme example was provided by Vicky who had never taken drugs before her romantic co-offender pressured her into doing so; “At first I used to say that I didn't want to do it. He offered it me all the time, used to call me a pussy for not wanting any and eventually, I just couldn't be arsed with him being on my case all the time so I did it." Her ex-boyfriend became her drug dealer and then tricked her into taking heroin, intensifying her addiction:

It started off with just weed and stuff like that and by the end he get me into heroin and all sorts. I remember one time he told me he had given me a bag of brown (weed) and I took it as normal, he started laughing and said it was fucking heroin. Fucking heroin. That was the first time I took it and it went from there really.

Danielle had a similar story to the extent that it was her male partner at the time that introduced her to drugs; "He was on, the guy I was with, he was on drugs. He introduced me to the drugs". For both Danielle and Vicky, although drug-taking became a central motivating factor for their continued offending, it was their male co-offender who introduced them to drugs. However, Danielle was clear that it was her who made the choice to take them; he did not force or coerce her to do so. She said; "I'd done it myself. He didn't put me on it". She reinforced her own agency by explaining how when she left him she continued to offend to support her addiction; "When we'd finished, when I'd gone, and I had to support my own habit then. So that's when I started doing it myself ... 'cause I had no-one to rely on ...". Despite Danielle's assertions of her own agency, it is clear that her ex-boyfriend/ co-offender was the 
one who first introduced her to drugs, and at the very least made the drugs easily available, thus influencing her use of them. Finally, as previously discussed, Jane explained how the friends that she co-offended with used her house both to sell and use drugs; "Cause people, they just want to use my house. Somewhere to take the drugs and that ...". She did not suggest that any of them had introduced her to drugs, but believed that they had "taken advantage a bit" of her being a "soft touch".

For these three women, co-offending and drug use were fundamentally intertwined as offending motivations albeit to differing extents and in different ways. In this way it is possible to see how pathways into crime and offending motivations of these women were complex and multi-faceted, involving the intersection of multiple factors simultaneously, or a chain reaction where one factor overlapped with another shortly afterwards. Indeed, for both Danielle and Vicky it was their romantic co-offenders that introduced them to drugs, which resulted in a number of years of drug taking, and in turn, shoplifting and theft. In this way, the typical approach of dichotomising and categorising these women as specific 'types' of offenders, or into specific offending categories, does not reflect the complex realities of their lived experiences.

\section{Economic circumstances}

Two women indicated that their economic circumstances motivated their involvement in offending, albeit to different degrees. Rachel was involved in benefit fraud alongside her expartner and another male co-offender. Whilst she was clear that her ex-partner pressured her into the offending (discussed previously), she also emphasised the importance of their financial situation on the pressure he put her under and ultimately her decision to offend. She explained; "We were skint, we wouldn't have the food. We wouldn't ... we wouldn't have had 
enough ... that was the only way we could afford to buy the house and have a home of our own. That was the starting thing". She also mentioned how her own economic aspirations for herself and her family impacted upon her involvement in the fraud; "We couldn't really afford to buy the house. But I wanted a house ... We wouldn't have been able to get the house". Thus for Rachel, whilst her co-offenders were arguably the pathway for her involvement in criminal behaviour, her economic circumstances and personal aspirations also played a role in her offending motivations and ultimately her pathway into crime, as well as the specific offences committed. This highlights that for Rachel, her pathway into crime and offending motivations overlapped, evidencing the 'messy' and chaotic nature of her offending circumstances.

Sarah also disclosed difficult economic circumstances in relation to her offending. For her, these circumstances arose as a result of previous co-offending and a traumatic life event, which then impacted upon further offending in relation to her economic circumstances. The traumatic life event led to her developing post-traumatic stress disorder and she lost custody of her two children to their father. Consequently, she had nowhere to live and no family to turn to for support. She explained; “I didn't care if I went to jail, 'cause at least I'd have a roof over me. Sometimes if I didn't have nowhere to sleep that night, I'd walk in Asda, rip clothes off the rails, and just chuck 'em on the floor, just so they' $d$ ring the police on me". Whilst there was clearly a complex chain of events involved in her offending, at least part of Sarah's motivation for committing certain offences could be attributed to the fact that she was homeless. Indeed, from the above quote it is clear that she committed some offences to combat the immediate consequences (i.e. homelessness) of her economic situation. 


\section{'Significant life events'}

Another offending motivation for two of the women falls into what we have termed a 'significant life event', that is an event that significantly impacted or affected the women's life, decisions, and subsequent actions. For Sarah this was her daughter being diagnosed with cancer. As she explained; "I lost the plot ... because, erm, my daughter had cancer. So, and I had two new-born babies, I just went [makes crashing noise]". Whilst she had offended before this event, both individually and with others, it was clear that this, and the subsequent mental health problems she experienced, as well as losing custody of her children, was a catalyst for her to engage in further offending behaviour. This significant life event began a chain of events for Sarah, with multiple intersecting factors, that led her to re-offend.

Danielle also cited a significant life event as a catalyst for her continued offending. She was dragged into a car and physically assaulted by a man whilst waiting at a bus stop, before managing to escape and get help. Whilst she admitted to having previously taken drugs before this incident, she explained; "I think ... when I started getting in trouble with the police was after when that happened ... that's when I just went off the rails". Such examples highlight the importance of understanding 'turning point moments' as both offending motivations and pathways into and out of crime for women co-offenders (Goodey, 2000). These cases, particularly Sarah's, also highlight how multiple factors can decussate around, or follow on from, a significant life event to create a complex and multi-faceted environment within which women are motivated to offend. 


\section{Discussion}

Contextualising the role of the co-offending relationship

From our analysis of the women's experiences it is clear that co-offending relationships influenced women's offending behaviour. For several women it was the relationship with their romantic co-offender that was their initial pathway into crime, emphasising the significance of this relationship on their criminal behaviour. For women who co-offended with friends, particularly female friends, the importance of this relationship to the 'success' of their offending enterprises and continued motivations to offend also emphasises the relevance of the co-offending relationship. In this way, our analysis has emphasised the importance of understanding the impact of co-offending relationships, whatever form they take, when considering the experiences of female offenders.

Whilst the findings from this research broadly support some of that within the existing literature, in particular the experience of women co-offending with intimate partners as a result of love or fear (Jones, 2008; Richie, 1996), we have also demonstrated that several additional factors often intersect with the co-offending relationship when motivating women to commit crime. Our analysis highlights how various factors and vulnerabilities, such as substance misuse, financial issues, and significant life events overlapped, creating multiple offending motivations. In this way, it is possible to see that whilst co-offending with an intimate partner in particular was a key pathway into crime for many of the women, it was not their sole ongoing motivation for continued offending. Rather there was clear overlap, albeit to varying degrees, between the co-offending relationship and other experiences in the women's lives, which motivated their continued offending. 
The impact of various factors overlapping with the co-offending relationship is not something that has previously been considered in the context of co-offending. As such, this is something that would benefit from further focus within research to develop more accurate understandings of women's life experiences. Indeed, to fully develop understanding regarding the experiences of women who co-offend, focus needs to be centred on the context of this offending and their relationships with co-offending partners. In particular, this contextualised approach needs to focus on other life factors or experiences that intersect with the co-offending relationship to influence their pathways into crime and or/ motivations for continued offending.

The role of agency

The issue of agency also featured within women's narratives. This emerged not only in relation to co-offending relationships, but also drug use and economic circumstances. It was clear that when considering their motivations for offending, reflecting upon their choices was important for many women. As highlighted earlier in the article, the women recognised their agency to varying degrees. In doing so, they repeatedly emphasised the ways in which the choices they had, and those they actually made, were limited and influenced by their life circumstances, particularly the relationship with their romantic co-offender. Indeed, all of the women who co-offended with an intimate male partner highlighted the way in which this relationship negatively impacted upon their agency. In contrast, as noted earlier, Danielle and Sarah, who co-offended with female friends (and also with intimate male partners), more readily acknowledged their choices in relation to the crimes they committed with friends. This highlights that women felt their romantic co-offenders limited and influenced their choices in 
a way that their female co-offenders did not. This in turn underscores the importance of understanding the ways in which gender roles, power, and inequality can influence cooffending relationships.

The existing approach to the issue of women's agency within the literature, both feminist and otherwise, is typically reductionist, with some scholars asserting women's status as autonomous individuals, choosing to commit crime as a conscious and deliberate act (see, e.g. Morrisey, 2003), and others negating their agency altogether by focusing on their victimisation, oppression, and pathology. As Maher (1997) notes, women who offend are typically viewed to be either wholly independent agents or as lacking control in relation to their offending behaviour. In other words, the main question that arises is "were these women 'offenders' in the full sense of the term, or should they be seen as essentially 'victims'?" (Jones 2008: 149). As a result, little research opts to acknowledge women's agency, whilst also recognising that this may be impacted by women's personal circumstances such as poverty, or a coercive / abusive relationship (see, e.g. removed for review, 2016; Richie 1996; Ballinger 2000; removed for review, 2013).

The findings presented here demonstrate how women repeatedly asserted AND contextualised their choices. This contextualisation related to abuse/coercion/violence from male partners, as well as drug addiction, economic circumstances, and the impact of friends. This highlights the importance of future research in this area, as well as on female offenders more broadly, taking an approach which first recognises women as agents, and secondly recognises the broader social context and situations within which their choices are made. In doing so, 'degrees' of agency can be acknowledged and considered for offending women, 
allowing, for example, both their agency and victimisation to be simultaneously recognised where an abusive co-offender is involved.

\section{Women as victims and offenders}

Finally, and linked to both of the discussion points above, this study highlights the importance of recognising co-offending women as both victims and offenders. As noted earlier in the article, all of the women who co-offended with a romantic male partner reflected negatively on the relationship, highlighting the coercion, fear, and emotional and physical abuse that they endured. Despite this, all of the women clearly recognised themselves as offenders. In this way, the women appeared to be able to identify themselves as simultaneously being victims and offenders.

This contrasts with criminal justice and broader societal responses to such women which often encourage a dichotomisation of victim or offender 'labels'. This has the consequence of victimisation either being centralised to the extent that women's agency as offenders is completely denied, or their victimisation is minimised or ignored (see, e.g. removed for review 2013). Such issues are evident in the recently published Female Offender Strategy (2018). Although this indicates that women offenders often experience victimization, this is not explored in any significant length. Much more could be included in relation to the influence of co-offending and structural constraints on women's criminalisation. The findings of this research could therefore contribute to the continued policy development and support provision provided to women offenders/ co-offenders. 
Furthermore, criminologists have tended to explore the victim-offender overlap within particular contexts, for example, considering whether offending increases the chance of victimisation more generally (Lauritsen, Laub and Sampson 1991), and the similarities between victims and offenders in terms of demographics and behaviours (Schrek et al, 2008). This overlap has also been explored within sex work research, as sex workers are often perceived as either victims of problematic drug use and/or sexual exploitation/ objectification, or as engaging in criminal activities, otherwise known as the Madonna/ whore binary (Sanders, 2005). There has however been little exploration of the victim-offender overlap within the context of female co-offending (notable exceptions include, Richie 1996, removed for review 2013, removed for review 2016). The experiences of women in this study are particularly noteworthy, as their offending and victimisation often occurred within the context of the same relationship; co-offending and intimate-partner abuse. This highlights the unique features of this type of victim-offender overlap and thus the issues with separating and dichotomising victims and offenders into distinct categories.

\section{Concluding thoughts}

All of the women involved in our study highlighted the importance of co-offending relationships in relation to their pathways into crime and/ or continued motivations to offend. Although co-offending with a male, intimate partner in particular was typically a central pathway into crime for participants, this often overlapped with other factors and circumstances within their lives, such as substance abuse and economic circumstances. The impact of co-offending relationships on women's choices varied. However, it was clear that women who co-offended with female friends much more readily acknowledged their agency 
than those who co-offended with intimate male partners, highlighting the potential impact of gendered roles and power dynamics in this context. Our findings also demonstrate the significance of understanding the complex and multi-faceted nature of co-offending women's lives and decision-making processes. The 'messiness' of such women's lives contradicts the often-prescriptive categorisations in much of the existing co-offending literature, underscoring the need for a departure from such an approach and a move towards a contextbased view that recognises the complexities of women's lives.

Whilst providing novel insights into the experiences of co-offending women in the UK, our study does have limitations, particularly in relation to the representativeness of the sample, e.g. geographic area, socio-economic background, sexuality, and ethnicity, as well as its size. As such, future research in this area would benefit from engaging a larger, more crosssectional group of women to test the findings from this study, and to consider whether, and the extent to which, findings are impacted by intersecting characteristics, such as class, race, and sexuality (Crenshaw, 1993). This would help to develop further understandings in relation to the lived experiences of co-offending women. Nevertheless, the findings presented here highlight the importance of listening to, and centralising, the narratives of co-offending women in order to develop appropriate policies, practice, and support for them.

\section{References}

Ballinger, A. (2000) Dead woman walking. Aldershot: Ashgate.

Barlow, C. (2016). Coercion and women co-offenders: A gendered pathway into Crime. Bristol: Policy Press 
Batchelor, S. (2009). Girls, gangs and violence: Assessing the evidence. Probation Journal, 56 (4), 399-414.

Becker, S., \& McCorkel, J.A (2011) The gender of criminal opportunity: The impact of male cooffenders on women's crime. Feminist Criminology, 6 (2), 79-110.

Belknap, J. (2007). The invisible woman: Gender crime and Justice ( $3^{\text {rd }}$ edition). Belmont, CA: Thomson Wadsworth Publishing.

Carlen, P. (1988). Women, Crime and Poverty. Milton Keynes: Open University Press.

Chesney-Lind, M., \& Sheldon, R. G. (2004). Girls, delinquency and juvenile justice (3rd edition). Belmont, CA: Wadsworth/Thompson Learning.

Conway, K.P. \& McCord, J. (2002). A longitudinal examination of the relation between cooffending with violent accomplices and violent crime, Aggressive Behaviour, 28, 97-108. Doi: 10.1002/ab.90011.

Covington, S. (1988). The relational theory of women's psychological development: Implications for the criminal justice system. In R. T. Zaplin (Ed.). Female offenders: Critical perspectives and effective interventions. Gaithersburg, MD: Aspen Publishers.

Daly, K (1994). Gender, Crime and Punishment. New Haven, CT: Yale University Press.

Daly, K., \& Chesney-Lind, M. (1996). Feminism and criminology. In P. Cordella and L. Siegel (Eds.) Readings in Contemporary Criminological Theory (340-364). Boston, MA: Northeastern University Press.

Gilligan, C (1982). In a different voice-psychological theory and women's development. Cambridge, MA: Harvard University Press. 
Goodey, J. (2000). Biographical lessons for Criminology, Theoretical Criminology, 4, 473-498.

Harding, S (1981). Feminism and Methodology: Social Science Issues. Bloomington: Indiana University Press.

Jones, S. (2008). Partners in crime: A study of the relationship between female offenders and their co-defendants, Criminology and Criminal Justice, 8 (2), 147-164.

Jones, S. (2011). Under Pressure: Women who plead guilty to crimes they have not committed, Criminology and Criminal Justice, 11 (1), 77-90.

Koons-Witt, B. \& Schram, P.J. (2003). The prevalence and nature of violent offending by females. Journal of Criminal Justice,31(4), 361-371.

Lauderdale, M. \& Burman, M. (2009). Contemporary patterns of female gangs in correctional settings, Journal of Human Behavior in the Social Environment, 19 (4), 258-280.

Lauritsen, J. L., Sampson, R. J., \& Laub, J. H. (1991). The link between offending and victimization among adolescents. Criminology, 29 (2), 265-292.

Maher, L. (1997). Sexed Work: Gender, Race and Resistance in a Brooklyn Drug Market. Oxford: Oxford University Press.

McGloin, J.M., Sullivan, C.J., Piquero, A., \& Bacon, S. (2008). Investigating the stability of cooffending and co-offenders among a sample of youthful offenders. Criminology, 46 (2), 155188.

Morrisey, B (2003). When women kill: Questions of agency and subjectivity. London: Routledge. 
Mullins, C., \& Wright, R (2003). Gender social networks and residential burglary. Criminology, $41(3), 813-840$.

Pettersson, T (2005). Gendering delinquent networks: A gendered analysis of violent crimes and the structure of boys and girls co-offending networks. Young Nordic Journal of Youth Research, 13 (3), 247-267.

Reid, K., Flowers, P. \& Larkin, M. (2005). Exploring the lived experience. The Psychologist, 18, 20-23.

Reiss, A.J, Jr., \& Farrington, D.P (1991). Advancing knowledge about co-offending: Results from a prospective longitudinal survey of London males. Journal of Criminal Law and Criminology, 82 (2), 360-395.

Weare, S. (2013). "The mad", "the bad", "the victim": Gendered constructions of women who kill within the criminal justice system. Laws, 2 (3), 337- 361.

Weare, S. (2017). Bad, mad or sad? Legal language, narratives and identity constructions of women who kill their children in England and Wales. International Journal for the Semiotics of Law, 30 (2), 201-222

Richie, B.E (1996) Compelled to Crime: The Gender Entrapment of battered black women. NY: Routledge.

Sanders, T. (2005). Sex work: A risky business. Devon: Willan Publishing.

Schreck, C. J., Stewart, E. A., \& Osgood, D. W. (2008). A reappraisal of the overlap of violent offenders and victims. Criminology, 46 (4), 871-906. 
Seal, L. (2010). Women, murder and femininity: Gender representations of women who kill. London: Palgrave.

Simpson, S.S., Yahner, J.L. \& Dugan, L. (2008). Understanding women's pathways to jail: Analysing the lives of incarcerated women. The Australian and New Zealand Journal of Criminology, 41 (1), 84-108.

Smith, D (1989). The Everyday World as Problematic: A Feminist Sociology. Boston, MA: Northeastern University Press.

Smith, J.A. (2004). Reflecting on the development of interpretative phenomenological analysis and its contribution to qualitative research in psychology. Qualitative Research in Psychology, 1 (3), 39-54.

Smith, J.A., Flower, P. \& Larkin, M. (2009). Interpretative phenomenological analysis: Theory, method and research. London: Sage.

Surratt, H., James, I., Kurtz, S. \& Kiley, M. (2004). Sex work and drug use in a subculture of violence. Crime \& Delinquency. 50 (1), 43-59.

Walklate, S. (2001) Gender, crime and criminal justice. Devon: Willan Publishing.

Warr, M. (1996). Organization and instigation in delinquent groups. Criminology, 36 (1), 1137.

Welle, D., \& Falkin, G. (2000) The everyday policing of women with romantic co-defendants: An ethnographic perspective, Women and Criminal Justice, 11 (2), 45-65.

Wincup, E. (2016). Gender, recovery and contemporary UK drug policy. Drugs and Alcohol Today, 16 (10), 39-48. 
Worrall, A. \& Gelsthorpe, L. (2009). 'What works' with women offenders: The past 30 years. Probation Journal, 56 (4), 329-345. 